\title{
Evaluating viability of sea turtle foraging populations at high latitudes: age and growth of juveniles along the French Atlantic coast
}

\author{
Larisa Avens ${ }^{1, *}$, Florence Dell'Amico ${ }^{2}$ \\ ${ }^{1}$ National Marine Fisheries Service, Southeast Fisheries Science Center, NOAA Beaufort Laboratory, 101 Pivers Island Rd, \\ Beaufort, NC 28516, USA \\ ${ }^{2}$ Aquarium La Rochelle, Centre d'Etudes et de Soins pour les Tortues Marines, Quai Louis Prunier BP4, \\ 17002 La Rochelle Cedex1, France
}

\begin{abstract}
Despite observations extending back several centuries, the presence of hard-shelled sea turtles in the eastern North Atlantic is often considered anomalous, as these species more typically inhabit lower latitudes. However, in recent years the occurrence of small juvenile loggerhead Caretta caretta, Kemp's ridley Lepidochelys kempii, and green sea turtles Chelonia mydas along the French Atlantic coast has increased, primarily in the Bay of Biscay. Concurrent increases in water temperature and northward range expansion for sub-tropical and temperate fish and invertebrate species in this area raise the possibility that sea turtles might inhabit French Atlantic waters as part of their normal range. To facilitate investigation of the nature of sea turtle occurrence in the eastern North Atlantic, we estimated for the first time length-at-age relationships and somatic growth rates for juveniles of these 3 sea turtle species through analysis of skeletal growth marks in humerus bones (skeletochronology) of individuals found along the French Atlantic coast. These results were compared with age and growth data yielded by studies of juveniles inhabiting other, more typical foraging areas, but likely originating from some of the same reproductive populations. Age and growth of juvenile loggerhead and green sea turtles in the French Atlantic were comparable to other juvenile foraging populations, indicating that the turtles could have been occupying suitable foraging habitat prior to stranding. In contrast, size-at-age and growth rates for Kemp's ridleys in the area were lower, suggesting that environmental conditions in the French Atlantic may be sub-optimal for this species.
\end{abstract}

KEY WORDS: Loggerhead $\cdot$ Caretta caretta $\cdot$ Kemp's ridley $\cdot$ Lepidochelys kempii $\cdot$ Green sea turtle $\cdot$ Chelonia mydas $\cdot$ Skeletochronology

\section{INTRODUCTION}

Although hard-shelled sea turtles (Family Cheloniidae; Oppel 1811) are typically associated with warm-water habitats at lower latitudes, they have long been known to occur in the waters of the European Atlantic continental shelf (see Fig. 1), with records dating back to the 17th century (Brongersma 1972). In order of decreasing incidence, species observed have been loggerhead Caretta caretta, Kemp's ridley Lepidochelys kempii, and green Che-

${ }^{*}$ Corresponding author: larisa.avens@noaa.gov lonia mydas sea turtles (Brongersma 1972, Witt et al. 2007, Dell'Amico et al. 2017). While larger individuals (particularly loggerheads) have been reported, records indicate that the majority of hard-shelled sea turtles sighted in this region are small juveniles (Brongersma 1972, Witt et al. 2007, Morinière \& Dell'Amico 2011). As sea turtles are ectotherms whose movements and biological functions are greatly influenced by ambient temperature, it is perhaps not surprising that reported strandings of these species, where individuals become debilitated and

() F. Dell'Amico and, outside the USA, the US Government 2018. Open Access under Creative Commons by Attribution Licence. Use, distribution and reproduction are unrestricted. Authors and original publication must be credited.

Publisher: Inter-Research · www.int-res.com 
wash ashore, are most prevalent during colder winter months (Witt et al. 2007). Evaluation of available stranding data, along with reports of sightings at sea, has revealed an overall increase in sea turtle occurrence in European shelf waters throughout the 20th century and on into the early 21st century (Brongersma 1972, Witt et al. 2007, Dell'Amico et al. 2017).

Along the French Atlantic coast, collection of sea turtle sighting and stranding data was initiated in the 1960s by Raymond Duguy (Musée Océanographique, La Rochelle) in the Les Pertuis Charentais region (see Fig. 1). Stranded marine turtles found alive were taken to the Aquarium La Rochelle for their rehabilitation and, subsequently, the Aquarium created the Centre d'Etudes et de Soins pour les Tortues Marines (CESTM), the only center in the region to rescue and rehabilitate live-stranded turtles. In addition, CESTM then began to coordinate standardized stranding response along the entire English Channel and Atlantic coasts through creation of the broader network Réseau Tortues Marines Atlantique Est (RTMAE) and to compile stranding information into a centralized database. Data yielded by this ongoing effort indicate that stranding patterns in this region generally parallel those observed in other areas in the eastern North Atlantic with respect to species composition, size distribution, seasonal occurrence, and increasing numbers (Brongersma 1972, Witt et al. 2007, Dell'Amico et al. 2017). Although some strandings occur on the coast of France adjacent to the English Channel, they are more prevalent to the south, in the Bay of Biscay (Fig. 1). There has been some indication that nutritional status of small juvenile sea turtles stranding on the European continental shelf is suboptimal (Witt et al. 2007). Along the French coast, stranding numbers are highest during colder months (Morinière \& Dell'Amico 2011) and turtles recovered then often appear emaciated; necropsies of dead strandings during this time of year have occasionally revealed empty digestive tracts (see Table A1 in the Appendix; F. Dell'Amico unpubl. data). Furthermore, it has been proposed that the increased presence of juvenile sea turtles in this area might simply reflect increases in their source populations, yielding a greater number of juveniles occupying oceanic habitat, of which a relatively constant proportion strays outside characteristic species ranges (Witt et al. 2007). As a result, it may be that suitable foraging grounds are not present along the French Atlantic coast, and that despite continued, long-term occurrence, the presence of juvenile hard-shelled sea turtles in this region is unintentional and deleterious (Witt et al. 2007).

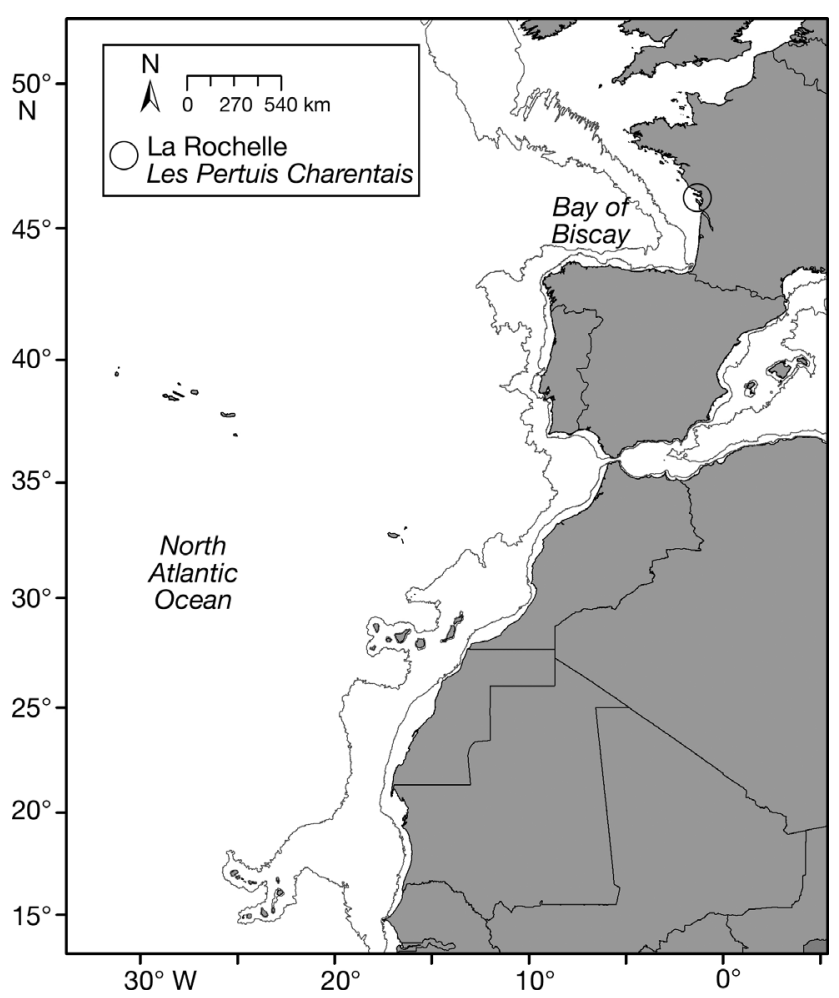

Fig. 1. Portion of the eastern North Atlantic Ocean considered in the current study

Alternatively, while it is possible that cheloniid sea turtles occurring in French Atlantic waters are 'waifs' lost to their respective populations, it may also be that at least some inhabit waters of the European continental shelf as part of their normal distribution (Brongersma 1972). Interestingly, although strandings along the French Atlantic coast do peak during the colder months (e.g. $59.5 \%$ of loggerheads stranded between January and April, 1988 to 2008), they also regularly occur during seasons when temperature is not expected to be a limiting factor (Table A1) (Morinière \& Dell'Amico 2011, Dell'Amico et al. 2017). The Bay of Biscay has been characterized as a biological 'hotspot'. Its complex oceanography includes persistent coastal and shelf upwelling, seasonal thermal fronts, nutrient input from large rivers, and regular formation of eddies that transport nutrientrich coastal waters away from shore (Lavin et al. 2004, Gibson 2005, Michel et al. 2009). These features sustain elevated levels of primary production (Lavin et al. 2004, Gibson 2005), as well as regular, large-scale jellyfish blooms (Doyle et al. 2008, Lilley et al. 2009), supporting high organismal diversity in the region (Lavin et al. 2004, Gibson 2005). Furthermore, studies have documented long-term increases in water temperature in the Bay of Biscay, correspon- 
ding with a northward range shift for numerous subtropical and temperate species (Lavin et al. 2004, Blanchard \& Vandermeirsch 2005, Hermant et al. 2010, Phillippart et al. 2011). Live-stranded loggerhead turtles that have been rehabilitated and instrumented with satellite tags prior to release have exhibited residency within the Bay of Biscay (Morinière \& Dell'Amico 2008, 2011, Dell'Amico \& Morinière 2011). In addition, both live-stranded and incidentally captured loggerheads and Kemp's ridleys that were tagged and released have been observed again in the Bay after periods of time ranging from days to months (Dell'Amico \& Morinière 2010, 2013, Morinière \& Dell'Amico 2011) and those later recaptured had increased in weight (F. Dell'Amico unpubl. data). Consequently, the increasing presence of sea turtles in this area is somewhat ambiguous; it could be that their range has expanded in response to increased water temperature in productive habitat as it becomes more suitable for them, similar to other species documented in this area. However, as the majority of turtles inhabiting the region are small, oceanic stage juveniles and, as this life stage is particularly difficult to study (Bolten 2003), the question of residency remains unanswered.

To better understand the nature of hard-shelled sea turtle occurrence in this region, we characterized, for the first time in European Atlantic waters, length-at-age and growth patterns for juvenile loggerhead, Kemp's ridley, and green sea turtles through analysis of skeletal growth marks (skeletochronology; Avens \& Snover 2013) for individuals recovered along the French Atlantic coast. Comparison of these results with age and growth data yielded by studies of juveniles inhabiting other, more typical foraging areas, but potentially originating from some of the same source nesting populations, offers insight into whether juvenile sea turtles in the Bay of Biscay are outside suitable habitat, or perhaps represent the periphery of range use.

\section{MATERIALS AND METHODS}

When loggerhead Caretta caretta, Kemp's ridley Lepidochelys kempii, or green sea turtles Chelonia mydas were recovered dead during stranding response along the French Atlantic coast by CESTM, or were initially found alive but later died, the left front flipper was removed and frozen for future analysis. Stranding date, location, and carapace length measurements were also recorded (Fig. 2, Table A1; Dell'Amico \& Morinière 2012, 2014, 2015, 2016). Although straight-line carapace length measured from the nuchal notch to the longest posterior tip of the carapace $\left(\mathrm{SCL}_{\mathrm{n}-\mathrm{t}}\right)$ has been used for the majority of age and growth analyses, for some turtles only $\mathrm{SCL}_{\min }$, measured from the nuchal notch to the posterior notch, was available. For these individuals, $\mathrm{SCL}_{\min }$ was converted to $\mathrm{SCL}_{\mathrm{n}-\mathrm{t}}$ using the following

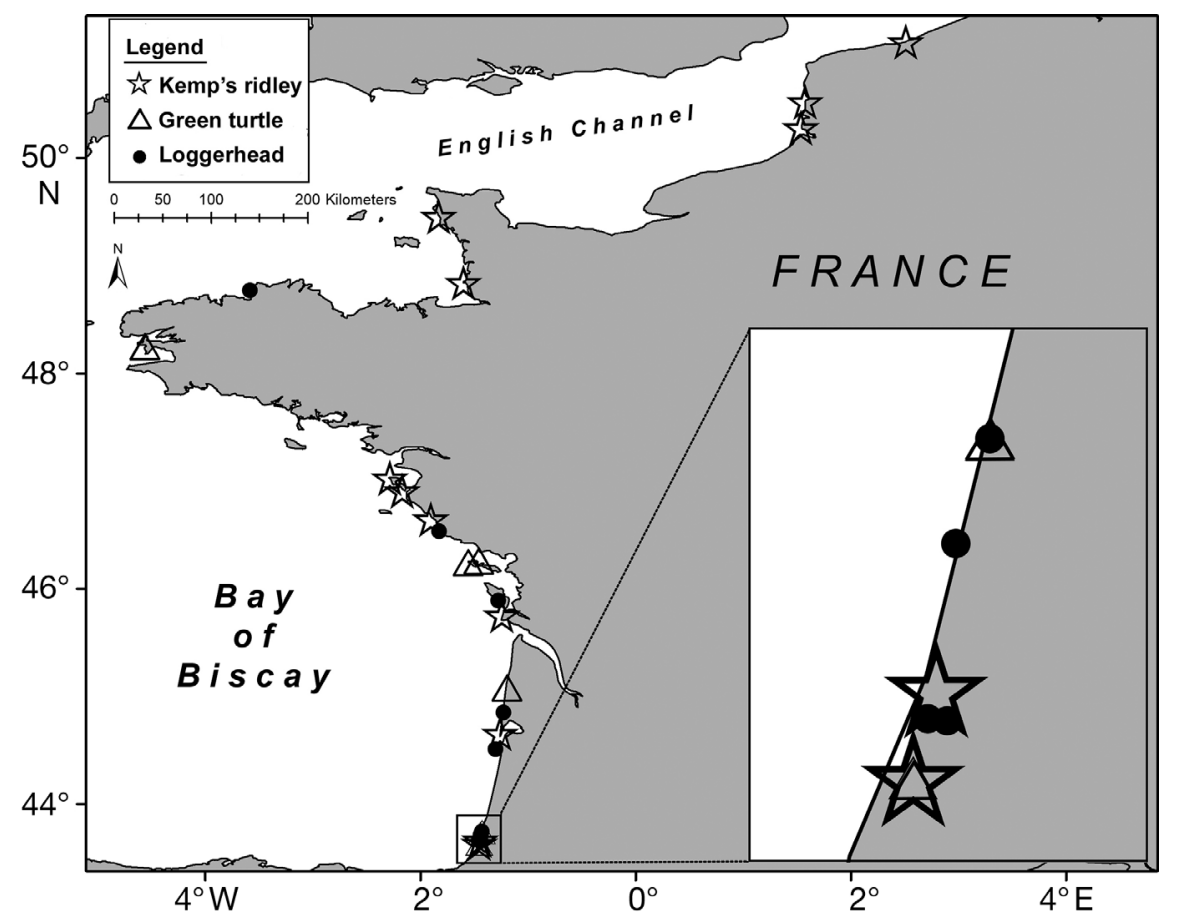

Fig. 2. French Atlantic coast showing stranding locations for the loggerhead Caretta caretta, Kemp's ridley Lepidochelys kempii, and green Chelonia mydas sea turtles from which samples were collected for the current study. Map inset: magnified portion of the southern coast, where several strandings occurred in close proximity 
equations generated using those turtles in the sample for which both measurements were available; for loggerheads $(\mathrm{n}=5)$ :

$$
\mathrm{SCL}_{\mathrm{n}-\mathrm{t}}=\left(1.0187 \times \mathrm{SCL}_{\min }\right)-0.2162
$$

for Kemp's ridleys $(\mathrm{n}=8)$ :

$$
\mathrm{SCL}_{\mathrm{n}-\mathrm{t}}=\left(1.0464 \times \mathrm{SCL}_{\min }\right)-0.7981
$$

and for green sea turtles $(\mathrm{n}=4)$ :

$$
\mathrm{SCL}_{\mathrm{n}-\mathrm{t}}=\left(1.0016 \times \mathrm{SCL}_{\min }\right)+0.5651
$$

Once flippers were thawed, the humerus bone was dissected out from the flipper, boiled to remove all surrounding tissue, and allowed to dry for several weeks prior to further processing. Full methods for sample preparation and skeletochronological analysis of sea turtle humeri are reviewed in Avens \& Snover (2013). Briefly, a 2 to $3 \mathrm{~mm}$ thick humerus cross-section was taken just distal to the deltopectoral process, which was then decalcified using Cal-Ex II fixative/decalcifier. A freezing stage microtome was used to collect $25 \mu \mathrm{m}$ thick sections, which were stained using diluted Ehrlich's hematoxylin. Stained sections were mounted in $100 \%$ glycerin on microscope slides and calibrated digital images of full humerus cross-sections at $4 \times$ were generated and used for analysis.

Two individuals independently assessed the position and number of lines of arrested growth (LAGs) that demarcate the outer edges of individual skeletal growth increments in each humerus section image, and then worked together to reach consensus if discrepancies arose. Once consensus was reached, measurements were taken of all LAG and humerus section diameters using cellSens image analysis software (Olympus). Accounting for any resorbed LAGs and converting LAG diameter measurements to estimates of $\mathrm{SCL}_{\mathrm{n} \text {-t }}$ was accomplished using correction factors and equations established for other populations of genetic composition similar to the study populations (Snover et al. 2007a,b, Goshe et al. 2010, Avens et al. 2012, 2013, 2015, 2017). As these prior analyses have validated annual LAG deposition for populations from which the turtles in the current study are likely to have originated, the assumption that one LAG was deposited each year was also applied in the current study. Age was assigned to each turtle to the nearest $0.25 \mathrm{yr}$ based on mean hatch date for the relevant population (see below for population designations), stranding date, and the number of observed (and, where applicable, resorbed) LAGs. Annual somatic growth rates were calculated by taking the difference between successive $\mathrm{SCL}_{\mathrm{n}-\mathrm{t}}$ estimates. Each calculated growth rate was assigned to the mean $\mathrm{SCL}_{\mathrm{n}-\mathrm{t}}$ for its associated growth increment, and then binned according to $10 \mathrm{~cm} \mathrm{SCL}_{\mathrm{n}-\mathrm{t}}$ size classes.

Data yielded by these analyses were then examined relative to possible source and geographically adjacent populations for these species, to allow comparison with SCL-at-age and somatic growth rate data from foraging areas where juvenile sea turtles more typically occur. The somewhat restricted sample size in the present study constrained feasible evaluation to qualitative, as opposed to statistical, comparison. However, the age and growth data yielded by this study represent the first for this region, and as such, hopefully represent a first step in more extensive study.

Genetic data support the prevalence of small, juvenile loggerheads of western North Atlantic origin in eastern North Atlantic foraging areas, including the European continental shelf (Monzón-Argüello et al. 2012). Mixed-stock analyses specific to loggerheads found in the Bay of Biscay indicated that approximately $50 \%$ of strandings originated from the southern Florida nesting population in the USA, consistent with the model of transport from the US Atlantic coast in the Gulf Stream and then the North Atlantic Current (Monzón-Argüello et al. 2012). In addition, large numbers of loggerheads also nest in the Cape Verde Islands in the eastern North Atlantic (Fig. 1), and genetic data revealed that $26 \%$ of juvenile Bay of Biscay loggerheads were found to originate from this nesting population (Monzón-Argüello et al. 2012). Although somatic growth data are not available specifically for Cape Verde juveniles, age and growth data yielded by the present study were compared with published information for this species and life stage from the Azores Islands, Atlantic US coast, and Atlantic-origin loggerheads in the Mediterranean (Bjorndal et al. 2003, Piovano et al. 2011, Avens et al. 2013, 2015).

As the reproductive distribution for Kemp's ridley sea turtles is predominantly constrained to the western Gulf of Mexico, there was no need to differentiate among potential source populations. French Atlantic Kemp's ridley age and growth data were therefore simply evaluated relative to those yielded by recent skeletochronological studies of juveniles of comparable size stranded both along the US Atlantic coast (Snover et al. 2007b) and in the Gulf of Mexico (Avens et al. 2017).

Finally, results of genetic analyses have indicated that juvenile green sea turtles stranded along the coast of Spain come from Atlantic and African populations, with no contribution from the Mediterranean 
(Carreras et al. 2014). Similarly, the waters surrounding the Cape Verde Islands are inhabited by juvenile green sea turtles originating from North and South American nesting populations, with up to $38 \%$ coming from Surinam (Monzón-Argüello et al. 2010). These genetic data suggest that juvenile green sea turtle occurrence in the Bay of Biscay likely results from a combination of Gulf Stream/North Atlantic Current transport and stochastic storm events, similar to loggerheads (Monzón-Argüello et al. 2012). Correspondingly, green sea turtle age and growth data generated by the current analyses were compared with those from juvenile foraging populations along the US Atlantic and Gulf coasts and western South Atlantic (Zug \& Glor 1998, Goshe et al. 2010, Avens et al. 2012, Bjorndal et al. 2017, Lenz et al. 2017), thought to originate from some of the same source populations (Bass \& Witzell 2000, Bass et al. 2006).

\section{RESULTS}

\section{Loggerheads Caretta caretta}

A total of 8 humerus samples were obtained from juvenile loggerheads 19.9 to $48.5 \mathrm{~cm} \mathrm{SCL}_{\mathrm{n}-\mathrm{t}}$ (mean \pm $\mathrm{SD}=27.9 \pm 9.7)$ stranded during 2010, 2013, and 2014. Estimates of age for these turtles ranged from 0.5 to $9 \mathrm{yr}$ old, with a mean of $3.9 \pm 2.6 \mathrm{yr}$.

While $S C L_{n-t}$ after the first year of growth following hatching fell within previous estimates from the region, subsequent size at age was slightly smaller (Fig. 3a). Comparison of size-class-specific growth rates indicated that growth for juvenile loggerheads that stranded along the French Atlantic coast was initially much slower than reported from other studies in the North Atlantic. However, once these turtles reached $>20 \mathrm{~cm} \mathrm{SCL}_{n-t}$, growth rates were either comparable to or greater than estimates for conspecifics in other areas (Fig. 3b).

\section{Kemp's ridleys Lepidochelys kempii}

A total of $12 \mathrm{Kemp}$ 's ridley humeri were obtained from turtles stranded between 2011 and 2015. Size range for these Kemp's ridleys was narrow, ranging from 21.1 to $26.9 \mathrm{~cm} \mathrm{SCL}_{\mathrm{n}-\mathrm{t}}$ (mean $=24.6 \pm 1.7$ ) and these juveniles were estimated to be between 1.5 and $2.5 \mathrm{yr}$ of age, with a mean of $1.9 \pm 0.5 \mathrm{yr}$. Length-atage for Kemp's ridleys along the French Atlantic coast was consistently less than that reported for the western North Atlantic and Gulf of Mexico (Fig. 4).
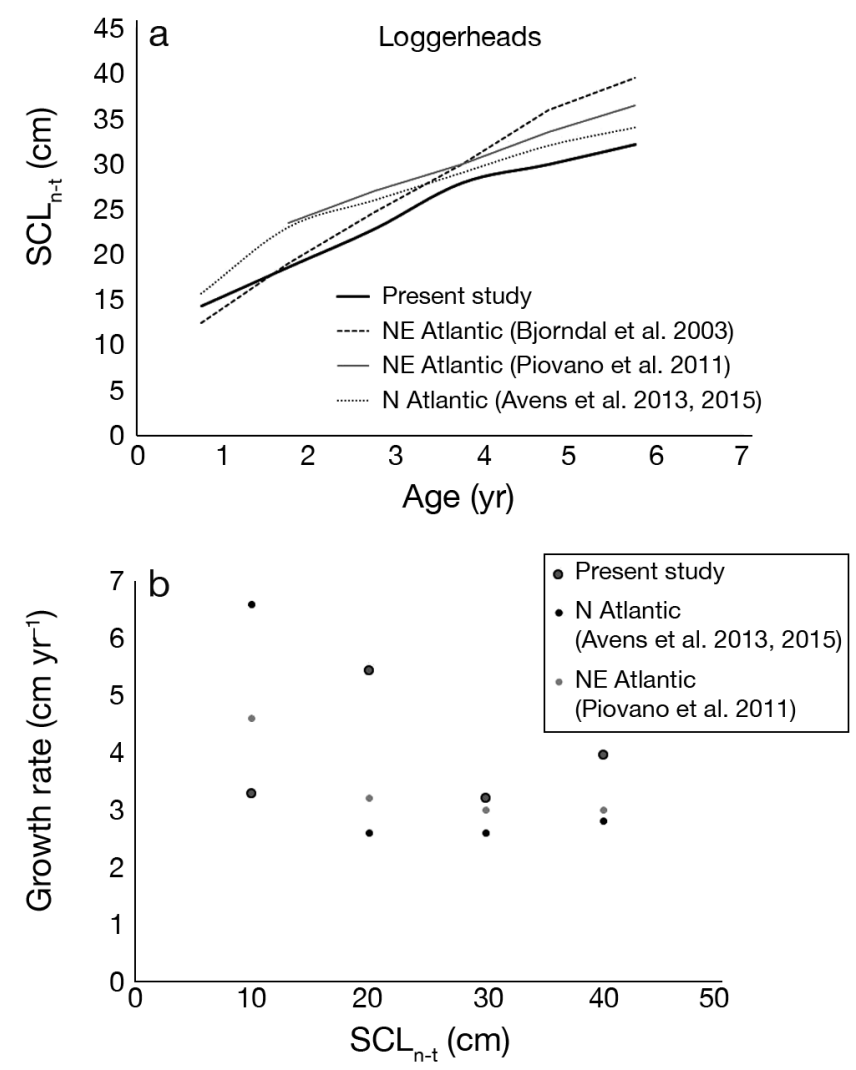

Fig. 3. (a) Age versus mean straight-line carapace length from the nuchal notch to posterior-most tip $\left(\mathrm{SCL}_{\mathrm{n}-\mathrm{t}}\right)$ and (b) mean annual somatic growth rate (i.e. change in carapace length) relative to $\mathrm{SCL}_{\mathrm{n}-\mathrm{t}}$ for loggerhead sea turtles along the French Atlantic coast (present study) compared to other juvenile loggerhead foraging populations of similar genetic origin

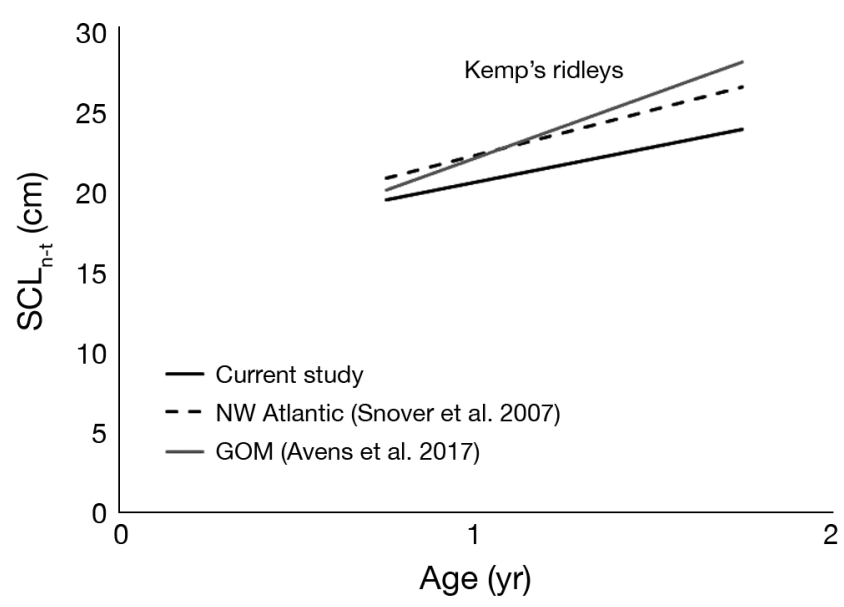

Fig. 4. Age versus mean straight-line carapace length from the nuchal notch to the posterior-most tip $\left(\mathrm{SCL}_{\mathrm{n}-\mathrm{t}}\right)$ for Kemp's ridley sea turtles along the French Atlantic coast compared to other juvenile foraging populations in the western North Atlantic and Gulf of Mexico 
Because all of the turtles were so young, few growth increments were available for growth rate comparisons. However, overall somatic growth rates for Kemp's ridleys in the eastern North Atlantic were lower than those reported for other areas (Table 1).

\section{Green sea turtles Chelonia mydas}

Humeri were collected from 6 juvenile green sea turtles ranging from 32.4 to $56.4 \mathrm{~cm} \mathrm{SCL}_{\mathrm{n}-\mathrm{t}}$ (mean = $39.8 \pm 8.7$ ) that stranded between 2012 and 2015. Age estimates for these turtles at stranding ranged from 4.5 to $12.5 \mathrm{yr}$, with a mean of $8 \pm 2.8 \mathrm{yr}$. Interestingly, although the length-at-age relationship for French Atlantic green sea turtles was lower than that reported for the northeastern Gulf of Mexico and western South Atlantic, it was comparable to and, at older ages greater than, the most recently described relationship for green sea turtles along the US Atlantic coast (Fig. 5a). Correspondingly, somatic growth rates were either higher than or fell within the range of those reported for conspecifics in the western North Atlantic and Gulf of Mexico (Fig. 5b).

\section{DISCUSSION}

In the present study, we characterized, for the first time, length-at-age relationships and somatic growth rates for juvenile hard-shelled sea turtles found along the French Atlantic coast, including loggerhead Caretta caretta, Kemp's ridley Lepidochelys kempii, and green sea turtles Chelonia mydas. This region is not usually thought of as a typical sea turtle foraging area despite centuries-long records of their occurrence (Brongersma 1972), yet the Bay of Biscay habitat

Table 1. Comparison of annual somatic growth rate (i.e. change in straight-line carapace length measured from the nuchal notch to posterior-most tip $\left[\mathrm{SCL}_{\mathrm{n}-\mathrm{t}}\right]$ ) for juvenile Kemp's ridley sea turtles along the French Atlantic coast (present study) and those of juveniles foraging in the western North Atlantic and Gulf of Mexico. Growth rates for all 3 studies were derived from skeletochronological analysis

\begin{tabular}{|c|c|c|c|c|c|}
\hline $\mathrm{SCL}_{\mathrm{n}-\mathrm{t}}$ & $\mathrm{n}$ & Mean & $\mathrm{SD}$ & Min. & Max. \\
\hline \multicolumn{6}{|c|}{ Present study: eastern North Atlantic } \\
\hline $20-29.9 \mathrm{~cm}$ & 5 & 3.1 & 2.2 & 1.3 & 6.1 \\
\hline \multicolumn{6}{|c|}{ Gulf of Mexico (Avens et al. 2017) } \\
\hline $20-29.9 \mathrm{~cm}$ & 131 & 6.8 & 3.3 & 0 & 15.4 \\
\hline \multicolumn{6}{|c|}{ NW Atlantic (Snover et al. 2007b) } \\
\hline $20-29.9 \mathrm{~cm}$ & & 4.4 & & & \\
\hline
\end{tabular}
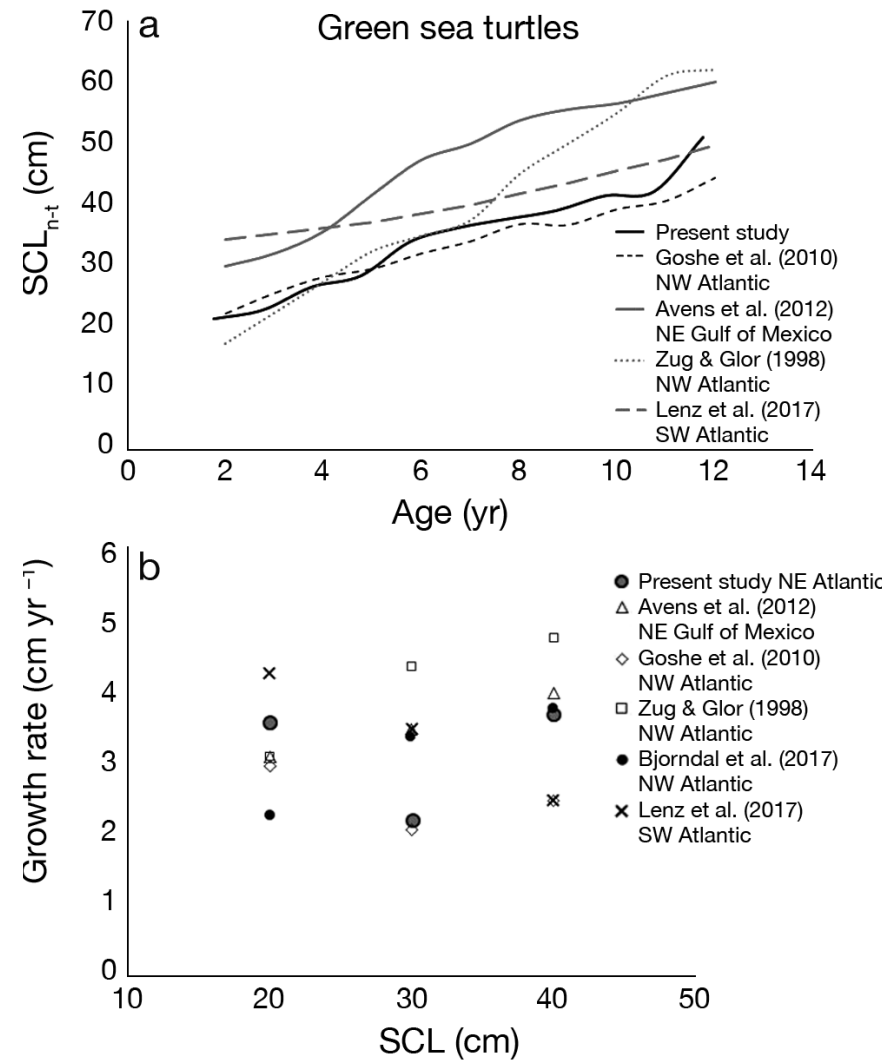

Fig. 5. (a) Age versus mean straight-line carapace length from the nuchal notch to posterior-most tip $\left(\mathrm{SCL}_{n-t}\right)$ and (b) annual somatic growth rate (i.e. change in carapace length) relative to $\mathrm{SCL}_{\mathrm{n}-\mathrm{t}}$ for green sea turtles along the French Atlantic coast (current study) compared to other juvenile green turtle foraging populations of similar genetic origin

along the French Atlantic coast (Fig. 1) is extremely productive and supports high biological diversity, including sub-tropical and temperate species (Lavin et al. 2004, Blanchard \& Vandermeirsch 2005, Gibson 2005, Hermant et al. 2010, Phillippart et al. 2011). In addition, temperatures throughout the water column in the Bay of Biscay and the northern French coast have been steadily increasing over the past decades and are projected to continue, facilitating northward range expansion for species typically occupying lower latitudes (Woehrling et al. 2005, Goikoetxea et al. 2009, Hermant et al. 2010, Phillippart et al. 2011).

Mean summer temperatures throughout the water column in the Bay of Biscay as of 2007 were 19 to $20^{\circ} \mathrm{C}$ (Hermant et al. 2010), with peak summer sea surface temperatures at one southeastern coastal location ranging from $\sim 20$ to $25^{\circ} \mathrm{C}$ (2001 to 2007; Goikoetxea et al. 2009). These temperatures fall within the habitable thermal range for sea turtles resident in other sub-tropical to temperate foraging areas (e.g. Read et al. 1996, Morreale \& Standora 1998, Epperly 
et al. 2007). For example, in Moreton Bay, Australia, where juvenile green sea turtles occupy seagrass foraging sites throughout the year, temperatures range from $15^{\circ} \mathrm{C}$ during the winter to $22^{\circ} \mathrm{C}$ in summer (Read et al. 1996). Similarly, juvenile green sea turtles in coastal Florida waters were observed to remain resident at water temperatures as low as 11 to $18^{\circ} \mathrm{C}$, establishing home ranges at temperatures greater than $25^{\circ} \mathrm{C}$ (Mendonça 1983). By contrast, along the US mid-Atlantic and northeast coast, summer and autumn temperatures can range from 15 to $33^{\circ}$ while winter temperatures fall below lethal limits (Morreale \& Standora 1998, Shertzer et al. 2018). Subsequently, cheloniid turtles in this region exhibit seasonal fidelity to foraging sites only during periods when temperatures are favorable, migrating to warmer waters during the winter (Shoop \& Kenney 1992, Morreale \& Standora 1998, Avens et al. 2003, McClellan \& Read 2009). To maintain this population-level behavior, the gains yielded by enhanced foraging opportunities in seasonally productive waters would then presumably offset the presumed high energetic cost of such long-distance migrations, as well as the potential risk of hypothermic stunning in the event of unexpected temperature decreases (Burke et al. 1991, Hawkes et al. 2007, Southwood \& Avens 2010, Williard et al. 2017). Similarly, it could be possible that juvenile hard-shelled sea turtles such as loggerheads, Kemp's ridleys, and green sea turtles inhabit the waters of the French Atlantic coast as a normal part of their distribution when water temperatures are suitable, to exploit seasonally productive foraging sites (Brongersma 1972). Here, we consider that possibility for each species through integration of the comparative age and growth data considered in the current study and other information available for sea turtles in this region.

\section{Loggerheads}

Loggerheads are the most common hard-shelled sea turtles found on the European continental shelf, and despite their winter peak in strandings, this species exhibits year-round presence (Witt et al. 2007, Dell'Amico et al. 2017). Modal size of loggerheads in the British Isles and France has been reported as 20 to $24.9 \mathrm{~cm} \mathrm{SCL}$, with small juveniles representing the majority of strandings (Witt et al. 2007, Morinière \& Dell'Amico 2011). Juvenile loggerheads of similar size also occupy foraging habitat in other widespread areas in the eastern North Atlantic such as the Azores Islands, Madeira, and Canary Islands (Fig. 1), which are thought to represent typical oceanic foraging areas for juveniles from the western North Atlantic population (reviewed by Mansfield \& Putman 2013). In addition, genetic analyses have demonstrated that juvenile loggerheads from the Cape Verde Islands (Fig. 1) commonly disperse northward and inhabit foraging areas near the Azores, Madeira, Canary Islands, and even the western Mediterranean (Marco et al. 2011), with transport thought to be facilitated by intermittent storm events (Monzón-Argüello et al. 2012). Similarly, genetic data indicate that approximately $50 \%$ of loggerhead strandings in the Bay of Biscay originated from the southern Florida nesting population and $26 \%$ were from the Cape Verde Island nesting population (Monzón-Argüello et al. 2012). Satellite tracking of small juvenile loggerheads suggests movement among these eastern North Atlantic foraging areas following the trans-Atlantic migration from the western portion of the ocean basin (McCarthy et al. 2010). Furthermore, satellite tracking of larger juvenile loggerhead turtles from the Canary Islands (mean $=47.4 \mathrm{~cm} \mathrm{SCL}$; Varo-Cruz et al. 2016) demonstrated use of foraging areas spanning an enormous geographic range, with focal areas in the Canary Islands, but also ranging as far north as Spain and Portugal (Varo-Cruz et al. 2016), close to the French Atlantic coast. Although few satellite telemetry data are available for the French Atlantic, livestranded loggerheads that were rehabilitated and released with satellite tags have exhibited extensive residency in the Bay of Biscay, one of which subsequently migrated southward to the Canary Islands (Morinière \& Dell'Amico 2008, 2011, Dell'Amico \& Morinière 2011).

Given the presence of small, juvenile loggerheads in other eastern North Atlantic foraging areas and connectivity among those locations, seasonal residency in the Bay of Biscay does not seem unreasonable, considering that summer water temperatures are suitable (Hermant et al. 2010) and gelatinous prey is predictably abundant (Doyle et al. 2008, Lilley et al. 2009). Furthermore, mark-recapture and telemetry data for loggerheads in the Bay of Biscay support residency for periods of up to 7 mo (Morinière \& Dell'Amico 2008, 2011, Dell'Amico \& Morinière 2010, 2011). Consistent with this assumption, in the current study we found that juvenile loggerhead age and growth from the French Atlantic are comparable to those observed in studies of other foraging areas thought to be more typical for juveniles of this species (Fig. 3a,b). Although $\mathrm{SCL}_{\mathrm{n}-\mathrm{t}}$ at deposition of the first LAG was slightly smaller than previously described, growth rates subsequent to the first year of life were relatively 
high, supporting the possibility of compensatory growth (Bjorndal et al. 2003) and access to appropriate foraging resources. As a trend of lower growth rates at higher latitudes has been previously noted for loggerheads in the North Atlantic (Bjorndal et al. 2013), the elevated somatic growth relative to other study populations for juveniles $>20 \mathrm{~cm} \mathrm{SCL}_{n-t}$ in the current study might suggest that these turtles were occupying suitable developmental habitat.

\section{Kemp's ridleys}

The Kemp's ridley sea turtle Lepidochelys kempii is the second most frequent hard-shelled sea turtle encountered in the European continental shelf region, including the French Atlantic coast, with a modal size for stranded individuals reported as 20 to $24.9 \mathrm{~cm}$ SCL (Witt et al. 2007), similar to juvenile loggerheads. Their presence seems unexpected, as nesting for the species is concentrated in the western Gulf of Mexico and juvenile distribution typically includes only waters of the Gulf and along the Atlantic coast of the USA (NMFS \& USFWS 2015). Views regarding whether Kemp's ridleys that leave the Gulf of Mexico eventually contribute to the reproductive population are mixed, even for those juveniles inhabiting foraging areas along the US Atlantic coast (Henwood 1987, Lazell 1980, Morreale \& Standora 2005, NMFS \& USFWS 2015). As a result, juvenile Kemp's ridley strandings along the European continental shelf have been thought to represent vagrants incidentally brought across the ocean basin via the Gulf Stream and North Atlantic currents to a region where they are not expected to survive (Collard \& Ogren 1990). However, as early as 1944, Archie Carr noted large numbers of Kemp's ridleys inhabiting US Atlantic waters as far north as Massachusetts (Lazell 1980), where summer coastal water temperatures at that time would have been comparable to those recently observed in the Bay of Biscay (Nixon et al. 2004). Subsequent studies and mass cold stunning events in Cape Cod Bay, Massachusetts, involving thousands of individuals, demonstrate the continued, extensive occupation of coastal habitat at high latitude along the northeast US coast by small juveniles (Morreale \& Standora 2005, NMFS \& USFWS 2015).

With respect to the frequency of trans-Atlantic migrations for the species, Bolten \& Martins (1990) described 2 occurrences of Kemp's ridleys in the Azores Islands, one in 1989 and the other from 1913, as well as 3 records of Kemp's ridleys from Madeira (Fig. 1). Manzella et al. (1988) reported that of
Kemp's ridleys head-started from 1978 to 1986 (i.e. captive-reared for $\sim 1 \mathrm{yr}_{;} \mathrm{n}=12422$ ) and released within the Gulf of Mexico, $0.6 \%$ were recovered in the east Atlantic (coasts of France, $\mathrm{n}=2$ and Morocco, $\mathrm{n}=1$ ). Two juvenile Kemp's ridleys have also been reported from the Mediterranean coast of Spain (Tomás et al. 2003). In Irish waters, 10 Kemp's ridleys have been recorded since the 1960s and a total of 23 have been reported from the United Kingdom (King \& Berrow 2009). Finally, since 1988, CESTM has documented a total of $50 \mathrm{Kemp}$ 's ridleys stranded along the French Atlantic coast, with approximately $50 \%$ of those occurring since 2010 (Dell'Amico et al. 2017). Taken together, available data indicate that species occurrence on the European continental shelf is not unusual, and is increasing in France (Dell'Amico et al. 2017), as well as in Spain (Carreras et al. 2014).

These numerous records notwithstanding, results from the present study indicate that size-at-age relationships and size-class-specific somatic growth rates for Kemp's ridleys along the French Atlantic coast are somewhat depressed relative to available published data (Snover et al. 2007b, Avens et al. 2017). This result may in turn indicate that the biological and/or physical characteristics of the environment inhabited by small juvenile Kemp's ridleys in the Bay of Biscay and English Channel are sub-optimal relative to those inhabited by foraging populations in the Gulf of Mexico and along the US Atlantic coast.

\section{Green sea turtles}

Green sea turtles occur infrequently in European continental shelf waters, with a 2007 review of available historic data suggesting that the species is not present in the region (Witt et al. 2007). However, occurrence appears to be increasing in waters of coastal Spain (both Atlantic and Mediterranean coasts; Carreras et al. 2014) and $>50 \%$ of the green sea turtle strandings along the French Atlantic coast occurred from 2012 onward (Dell'Amico et al. 2017). Yearling green sea turtles released on the Atlantic coast of Florida, USA, were subsequently recovered in the Azores and Madeira (Fig. 1), providing direct demonstration of the capacity for successful transAtlantic movements for juveniles of this species (Limpus \& Musick 1997). Consistent with these observations, genetic data indirectly support this type of movement, as many juvenile green sea turtles found along the coast of Spain and Cape Verde Islands originate from North and South American nesting 
beaches (Monzón-Argüello et al. 2010, Carreras et al. 2014).

The size range of stranded green sea turtles in this study included individuals large enough that they might have either begun or even completed transition to neritic habitat and possibly herbivory (Reich et al. 2007), raising the question of whether appropriate forage items are present in the French Atlantic region. In fact, this region historically hosted extensive seagrass Zostera marina beds, but in the 1930s these beds were greatly reduced due to onset of widespread disease (Godet et al. 2008). Overall, recovery has been slow, and in some areas decreases have continued (Martin et al. 2010); however, in a few locations in the Bay of Biscay and the northern coast of France, steady increases in the extent of seagrass have recently been observed (e.g. Godet et al. 2008, Barillè et al. 2010). Although it is not possible to address which type/s of forage items might be consumed by juvenile green sea turtles in the present study at this time, their length-at-age and somatic growth rate estimates were comparable to those from more typical habitats, indicating that suitable foraging environments in some form is present along the French Atlantic coast.

\section{CONCLUSIONS}

Characterizing the nature of sea turtle presence in the French Atlantic region is of particular interest, as all species considered in the current study are of conservation concern $\mathbf{1}$, yet this area is highly impacted by human activities such as large-scale commercial and recreational fishing, mariculture, and vessel traffic, among others (Lorance et al. 2009). While observations of stranded turtles during colder months indicate that these individuals are debilitated, telemetry and recapture data suggest that rehabilitated, healthy turtles are able to successfully forage in the Bay of Biscay when water temperatures are suitable (Morinière \& Dell'Amico 2008, 2011, Dell'Amico \& Morinière 2010, 2011，2013，F. Dell'Amico unpubl. data). Taken together, age and growth data from this study combined with historic records, genetic data, and environmental trends support the consistent presence of juveniles of 3 hard-shelled sea turtle species along the French Atlantic coast to an extent that might seem unexpected for this geographic area. The juvenile Kemp's ridleys examined in this study exhibited consistently slower growth and smaller

\footnotetext{
$\underline{1}$ https://iucn-mtsg.org/about/structure-role/red-list/
}

length-at-age, suggesting that these individuals might have found themselves in sub-optimal habitat. However, overall growth rates for juvenile loggerheads and green sea turtles were within the ranges documented for other more representative foraging populations, indicating that perhaps turtles of these species found along the coast of France are successfully foraging in this atypical area. If the Bay of Biscay truly represents a viable foraging area for juvenile sea turtles whose genetics indicate a western Atlantic origin, this would represent an expansion of the current model of ontogenetic habitat shifts for the species in this region (reviewed by Mansfield \& Putman 2013). Future studies integrating age and growth data from the current study with annual skeletal growth increment-specific stable isotope analysis from the same bone samples, as well as isotopic data from potential forage species (e.g. Ramirez et al. 2015, Turner Tomaszewicz et al. 2018), will provide useful insight into the timing and nature of transitions between foraging habitats and the potential ecological niche for sea turtles found in the Bay of Biscay.

Acknowledgements. We are grateful for the efforts of CESTM participants to collect the samples that made this study possible, to L. Stokes for facilitating sample import under CITES import permit 12US045532/9, and to L. R. Goshe for assistance with sample analysis. We also thank L. R. Goshe, J. Braun-McNeill, and anonymous reviewers for providing comments to improve the manuscript.

\section{LITERATURE CITED}

Avens L, Snover ML (2013) Age and age estimation in sea turtles. In: Wyneken J, Lohmann KJ, Musick JA (eds) The biology of sea turtles, Vol 3. CRC Press, Boca Raton, FL, p 97-134

Avens L, Braun-McNeill J, Epperly S, Lohmann KJ (2003) Site fidelity and homing behavior in juvenile loggerhead sea turtles (Caretta caretta). Mar Biol 143:211-220

Avens L, Goshe LR, Harms CA, Anderson ET and others (2012) Population characteristics, age structure, and growth dynamics of neritic juvenile green turtles in the northeastern Gulf of Mexico. Mar Ecol Prog Ser 458: 213-229

Avens L, Goshe LR, Pajuelo M, Bjorndal KA and others (2013) Complementary skeletochronology and stable isotope analyses offer new insight into juvenile loggerhead sea turtle oceanic stage duration and growth dynamics. Mar Ecol Prog Ser 491:235-251

Avens L, Goshe LR, Coggins L, Snover ML and others (2015) Age and size at maturation and adult-stage duration for loggerhead sea turtles in the western North Atlantic. Mar Biol 162:1749-1767

Avens L, Goshe LR, Coggins L, Shaver DJ and others (2017) Variability in age and size at maturation, reproductive longevity, and long-term growth dynamics for Kemp's 
ridley sea turtles in the Gulf of Mexico. PLOS ONE 12: e0173999

Barillè L, Robin M, Harin N, Bargain A, Launeau P (2010) Increase in seagrass distribution at Bourgneuf Bay (France) detected by spatial remote sensing. Aquat Bot 92:185-194

Bass AL, Witzell WN (2000) Demographic composition of immature green turtles (Chelonia mydas) from the east central Florida coast: evidence from mtDNA markers. Herpetologica 56:357-367

Bass AL, Epperly SP, Braun-McNeill J (2006) Green turtle (Chelonia mydas) foraging and nesting aggregations in the Caribbean and Atlantic: impact of currents and behavior on dispersal. J Hered 97:346-354

Bjorndal KA, Bolten AB, Dellinger T, Delgado C, Martins HR (2003) Compensatory growth in oceanic loggerhead sea turtles: response to a stochastic environment. Ecology 84: 1237-1249

Bjorndal KA, Schroeder BA, Foley AM, Witherington BE and others (2013) Temporal, spatial, and body size effects on growth rates of loggerhead sea turtles (Caretta caretta) in the Northwest Atlantic. Mar Biol 160:2711-2721

Bjorndal KA, Bolten AB, Chaloupka M, Saba VS and others (2017) Ecological regime shift drives declining growth rates of sea turtles throughout the west Atlantic. Glob Change Biol 23:4556-4568

Blanchard F, Vandermeirsch F (2005) Warming and exponential abundance increase of the subtropical fish Capros aper in the Bay of Biscay (1973-2002). C R Biol 328:505-509

Bolten AB (2003) Variation in sea turtle life history patterns: neritic vs. oceanic developmental stages. In: Lutz PL, Musick JA, Wyneken J (eds) The biology of sea turtles, Vol 2. CRC Press, Boca Raton, FL, p 243-257

Bolten AB, Martins HR (1990) Kemp's ridley captured in the Azores. Mar Turtle Newsl 48:23

Brongersma LD (1972) European Atlantic turtles. Zool Verh 121:1-318

* Burke VJ, Standora EA, Morreale SJ (1991) Factors affecting strandings of cold-stunned juvenile Kemp's ridley and loggerhead sea turtles in Long Island, New York. Copeia 1991:1136-1138

Carreras C, Monzón-Argüello C, López-Jurado LF, Calabuig $\mathrm{P}$ and others (2014) Origin and dispersal routes of foreign green and Kemp's ridley turtles in Spanish Atlantic and Mediterranean waters. Amphib-Reptil 35: 73-86

Collard SB, Ogren LH (1990) Dispersal scenarios for pelagic post-hatchling sea turtles. Bull Mar Sci 47:233-243

Dell'Amico F, Morinière P (2010) Observations des tortues marines en 2008 et 2009 (Côtes atlantiques françaises). Annales de la Société des Sciences Naturelles de la Charente-Maritime 10:69-76

Dell'Amico F, Morinière P (2011) Observations des tortues marines et des poissons-lunes en 2010 (Côtes atlantiques françaises). Annales de la Société des Sciences Naturelles de la Charente-Maritime 10:237-243

Dell'Amico F, Morinière P (2012) Observations des tortues marines et des poissons-lunes en 2011 (Côtes atlantiques françaises). Annales de la Société des Sciences Naturelles de la Charente-Maritime 10:353-361

Dell'Amico F, Morinière P (2013) Observations des tortues marines et des poissons-lunes en 2012 (Côtes atlantiques françaises). Annales de la Société des Sciences Naturelles de la Charente-Maritime 10:437-445
Dell'Amico F, Morinière P (2014) Observations des tortues marines et des poissons-lunes en 2013 (façade MancheAtlantique). Annales de la Société des Sciences Naturelles de la Charente-Maritime 10:551-557

Dell'Amico F, Morinière P (2015) Observations des tortues marines et des poissons-lunes en 2014 (façade MancheAtlantique). Annales de la Société des Sciences Naturelles de la Charente-Maritime 10:675-681

Dell'Amico F, Morinière P (2016) Observations des tortues marines et des poissons-lunes en 2015 (façade MancheAtlantique). Annales de la Société des Sciences Naturelles de la Charente-Maritime 10:771-776

Dell'Amico F, Méheust A, Morinière P (2017) Observations des tortues marines et des poissons-lunes en 2016 sur la façade Manche-Atlantique. Annales de la Société des Sciences Naturelles de la Charente-Maritime 10: 935-945

Doyle TK, Georges JY, Houghton JDR (2008) A leatherback turtle's guide to jellyfish in the North East Atlantic. In: Zaldua-Mendizabai N, Egana-Callejo A (eds) Marine turtles of the north east Atlantic: contributions for the first regional conference. Munibe Monographs, Nature Series 1. Aranzadi Society of Sciences, San Sebastian, p 15-21

* Epperly SP, Braun-McNeill J, Richards PM (2007) Trends in catch rates of sea turtles in North Carolina, USA. Endang Species Res 3:283-293

Gibson L (2005) A critical evaluation of the Bay of Biscay as a candidate for a Marine Protected Area. MSc thesis, University of Wales, Bangor

Godet L, Fournier J, van Katwijk MM, Olivier F, Le Mao P, Retière C (2008) Before and after wasting disease in common eelgrass Zostera marina along the French Atlantic coasts: a general overview and first accurate mapping. Dis Aquat Org 79:249-255

Goikoetxea N, Borja A, Fontán A, González M, Valencia V (2009) Trends and anomalies in sea-surface temperature, observed over the last 60 years, within the southeastern Bay of Biscay. Cont Shelf Res 29:1060-1069

* Goshe LR, Avens L, Scharf FS, Southwood AL (2010) Estimation of age at maturation and growth of Atlantic green turtles (Chelonia mydas) using skeletochronology. Mar Biol 157:1725-1740

Hawkes LA, Broderick AC, Coyne MS, Godfrey MH, Godley BJ (2007) Only some like it hot - quantifying the environmental niche of the loggerhead sea turtles. Divers Distrib 13:447-457

*Henwood TA (1987) Distribution and migrations of immature Kemp's ridley turtles (Lepidochelys kempi) and green turtles (Chelonia mydas) off Florida, Georgia, and South Carolina. Northeast Gulf Sci 9:153-159

*Hermant M, Lobry J, Bonjommeau S, Poulard JC, Le Pape O (2010) Impact of warming on abundance and occurrence of flatfish populations in the Bay of Biscay (France). J Sea Res 64:45-53

King GL, Berrow SD (2009) Marine turtles in Irish waters. Ir Nat J 30:1-30

Lavin A, Valdes L, Sanchez F, Abaunza P and others (2004) The Bay of Biscay: the encountering of the ocean and the shelf. In: Robinson AP, Brink K (eds) The sea, Vol 14B: the global coastal ocean. Interdisciplinary Regional Studies and Syntheses. Harvard University Press, Cambridge, MA, p 933-1001

Lazell JD Jr (1980) New England waters: critical habitat for marine turtles. Copeia 1980:290-295 
Lenz AJ, Avens L, Borges-Martins M (2017) Age and growth of juvenile green turtles Chelonia mydas in the western South Atlantic Ocean. Mar Ecol Prog Ser 568: 191-201

Lilley MKS, Houghton JDR, Hays GC (2009) Distribution, extent of inter-annual variability and diet of the bloomforming jellyfish Rhizostoma in European waters. J Mar Biol Assoc UK 89:39-48

Limpus CJ, Musick JA (1997) Habitat utilization and migration in juvenile sea turtles. In: Lutz PL, Musick JA (eds) The biology of sea turtles, Vol 1. CRC Press, Boca Raton, FL, p 137-163

Lorance P, Bertrand JA, Brind'Amour A, Rochet MJ, Trenkel VM (2009) Assessment of impacts from human activities on ecosystem components in the Bay of Biscay in the early 1990s. Aquat Living Resour 22:409-431

Mansfield KL, Putman NF (2013) Oceanic habits and habitats Caretta caretta. In: Wyneken J, Lohmann KJ, Musick, JA (eds) The biology of sea turtles, Vol 3. CRC Press, Boca Raton, FL, p 189-210

Manzella SA, Caillouet CW Jr, Fontaine CT (1988) Kemp's ridley, Lepidochelys kempi, sea turtle head start tag recoveries: distribution, habitat, and method of recovery. Mar Fish Rev 50:24-32

Marco A, Abelle Pérez E, Monzón-Argüello C, Martins S and others (2011) The international importance of the archipelago of Cape Verde for marine turtles, in particular the loggerhead turtle Caretta caretta. Zoologia Caboverdiana 2:1-11

Martin P, Sèbastien D, Gilles T, Isabelle A and others (2010) Long-term evolution (1988-2008) of Zostera spp. meadows in Arcachon Bay (Bay of Biscay). Estuar Coast Shelf Sci 87:357-366

McCarthy AL, Heppell S, Royer F, Freitas C, Dellinger T (2010) Identification of likely foraging habitat of pelagic loggerhead sea turtles (Caretta caretta) in the North Atlantic through analysis of telemetry track sinuosity. Prog Oceanogr 86:224-231

McClellan CM, Read AJ (2009) Confronting the gauntlet: understanding incidental capture of green turtles through fine-scale movements studies. Endang Species Res 10:165-179

Mendonça MT (1983) Movements and feeding ecology of immature green turtles (Chelonia mydas) in a Florida lagoon. Copeia 1983:1013-1023

Michel S, Treguier AM, Vandermeirsch F (2009) Temperature variability in the Bay of Biscay during the past 40 years, from an in situ analysis and a 3D global simulation. Cont Shelf Res 29:1070-1087

* Monzón-Argüello C, López-Jurado LF, Rico C, Marco A, López P, Hays GC, Lee PLM (2010) Evidence from genetic and Lagrangian drifter data for transatlantic transport of small juvenile green turtles. J Biogeogr 37 : 1752-1766

* Monzón-Argüello C, Dell'Amico F, Moriniére P, Marco A and others (2012) Lost at sea: genetic, oceanographic, and meteorological evidence for storm-forced dispersal. J R Soc Interface 9:1725-1732

Morinière P, Dell'Amico F (2008) Suivi des observations de tortues marines sur la côtes atlantique française depuis 1988. In: Zaldua-Mendizabai N, Egana-Callejo A (eds) Marine turtles of the north east Atlantic: contributions for the first regional conference. Munibe Monographs, Nature Series 1. Aranzadi Society of Sciences, San Sebastian, p 23-29
Morinière P, Dell'Amico F (2011) Synthèse des observations de tortues marines sur la façade Manche-Atlantique de 1988 á 2008. Bull Soc Herp Fr 139-140:131-141

Morreale SJ, Standora EA (1998) Early life stage ecology of sea turtles in northeastern US waters. NOAA Tech Memo NMFS-SEFSC-413

Morreale SJ, Standora EA (2005) Western North Atlantic waters: crucial developmental habitat for Kemp's ridley and loggerhead sea turtles. Chelonian Conserv Biol 4: 872-882

Nixon SW, Granger S, Buckley BA, Lamont M, Rowell B (2004) A one hundred and seventeen year coastal water temperature record from Woods Hole, Massachusetts. Estuaries 27:397-404

NMFS (National Marine Fisheries Service), USFWS (US Fish and Wildlife Service) (2015) Kemp's ridley sea turtle (Lepidochelys kempii) 5-year review: summary and evaluation. https://www.fisheries.noaa.gov/action/kempsridley-sea-turtle-5-year-reviews

Oppel M (1811) Die Ordnungen, Familien und Gattungen der Reptilien als Prodrom einer Naturgeschichte derselben. J. Lindauer, München

* Phillippart CJM, Anadón R, Danovaro R, Dippner JW and others (2011) Impacts of climate change on European marine ecosystems: observations, expectations, and indicators. J Exp Mar Biol Ecol 400:52-69

*Piovano S, Clusa M, Carreras C, Giacoma C, Pascual M, Cardona L (2011) Different growth rates between loggerhead sea turtles (Caretta caretta) of Mediterranean and Atlantic origin in the Mediterranean Sea. Mar Biol 158: 2577-2587

* Ramirez MD, Avens L, Seminoff JA, Goshe LR, Heppell SS (2015) Patterns of loggerhead turtle ontogenetic shifts revealed through isotopic analysis of annual skeletal growth increments. Ecosphere 6:244

Read MA, Grigg GC, Limpus CJ (1996) Body temperatures and winter feeding in immature green turtles, Chelonia mydas, in Moreton Bay, southeastern Queensland. J Herpetol 30:262-265

* Reich KJ, Bjorndal KA, Bolten AB (2007) The 'lost years' of green turtles: using stable isotopes to study cryptic lifestages. Biol Lett 3:712-714

* Shertzer KW, Avens L, McNeill JB, Hall AG, Harms CA (2018) Characterizing sex ratios of sea turtle populations: a Bayesian mixture modeling approach applied to juvenile loggerheads (Caretta caretta). J Exp Mar Biol Ecol 504:10-19

* Shoop CR, Kenney RD (1992) Seasonal distributions and abundances of loggerhead and leatherback sea turtles in waters of the northeastern United States. Herpetol Monogr 6:43-67

* Snover ML, Avens L, Hohn AA (2007a) Back-calculating length from skeletal growth marks in loggerhead sea turtles Caretta caretta. Endang Species Res 3:95-104

Snover ML, Hohn AA, Crowder LB, Heppell SS (2007b) Age and growth in Kemp's ridley sea turtles: evidence from mark-recapture and skeletochronology. In: Plotkin PT (ed) Biology and conservation of ridley sea turtles. The John Hopkins University Press, Baltimore, MD, p 89-105

Southwood A, Avens L (2010) Physiological, behavioral, and ecological aspects of migration in reptiles. J Comp Physiol B 180:1-23

Tomás J, Formia A, Fernández M, Raga JA (2003) Occurrence and genetic analysis of a Kemp's ridley sea turtle 
(Lepidochelys kempii) in the Mediterranean Sea. Sci Mar 67:367-369

Turner Tomaszewicz CN, Seminoff JA, Avens L, Goshe LR, Rguez-Baron JM, Peckham SH, Kurle CM (2018) Expanding the coastal forager paradigm: long-term pelagic habitat use by green turtles Chelonia mydas in the eastern Pacific Ocean. Mar Ecol Prog Ser 587:217-234

Varo-Cruz N, Bermejo JA, Calabuig P, Cejudo D and others (2016) New findings about the spatial and temporal use of the eastern Atlantic Ocean by large juvenile loggerhead turtles. Divers Distrib 22:481-492

Williard AS, Hall AG, Fujisaki I, McNeill JB (2017) Oceanic overwintering in juvenile green turtles Chelonia mydas from a temperate latitude foraging ground. Mar Ecol Prog Ser 564:235-240

Witt MJ, Penrose R, Godley BJ (2007) Spatio-temporal patterns of juvenile marine turtle occurrence in waters of the European continental shelf. Mar Biol 151:873-885

Woehrling D, Lefebvre A, Fèvre-Lehoërff G, Delesmont R (2005) Seasonal and longer term trends in sea temperature along the French North Sea coast 1975 to 2002. J Mar Biol Assoc UK 85:39-48

Zug GR, Glor RE (1998) Estimates of age and growth in a population of green sea turtles (Chelonia mydas) from the Indian River lagoon system, Florida: a skeletochronological analysis. Can J Zool 76:1497-1506

Appendix. Data associated with stranded turtles from which samples were collected for analysis in the present study. Italicized $\mathrm{SCL}_{\mathrm{n}-\mathrm{t}}$ values denote estimates generated using species-specific equations (Eqs. 1-3)

\begin{tabular}{|c|c|c|c|c|c|c|}
\hline Species & $\begin{array}{l}\text { Stranding date } \\
(\mathrm{mo} / \mathrm{d} / \mathrm{yr})\end{array}$ & $\mathrm{SCL}_{\text {min }}$ & $S C L_{n-t}$ & $\begin{array}{c}\text { Cause of stranding / } \\
\text { death }\end{array}$ & GI contents & $\begin{array}{c}\text { Decom- } \\
\text { position state }\end{array}$ \\
\hline Caretta caretta & $2 / 2 / 2010$ & 23.2 & 23.4 & Likely hypothermia & Partly full & Alive \\
\hline Caretta caretta & $5 / 22 / 2013$ & 21 & 21.2 & Pulmonary infection & Partly full + marine debris & Alive \\
\hline Caretta caretta & $6 / 4 / 2013$ & 25.3 & 25.6 & Pulmonary emphysema & Empty & Alive \\
\hline Caretta caretta & $6 / 19 / 2013$ & 29 & 29.3 & Incidental capture & Full + marine debris & Fresh dead \\
\hline Caretta caretta & $7 / 29 / 2013$ & 47.7 & 48.5 & Incidental capture & Full & Alive \\
\hline Caretta caretta & $2 / 26 / 2014$ & 19.6 & 19.9 & Likely oil pollution & Empty & Alive \\
\hline Caretta caretta & $3 / 4 / 2014$ & 20.3 & 20.4 & $\begin{array}{c}\text { Wound on the } \\
\text { skull caused by a } \\
\text { propeller and drowning }\end{array}$ & Liquid content & Alive \\
\hline Caretta caretta & $10 / 10 / 2014$ & 34.5 & 34.7 & Unknown & Partly full+marine debris & $\begin{array}{c}\text { Very } \\
\text { putrefied }\end{array}$ \\
\hline Chelonia mydas & $1 / 4 / 2012$ & 56 & 56.7 & Likely hypothermia & Empty & Alive \\
\hline Chelonia mydas & $1 / 25 / 2013$ & 31.8 & 32.4 & $\begin{array}{l}\text { Likely combination of } \\
\text { hypothermia and inci- } \\
\text { dental capture/drowning }\end{array}$ & Partly full+marine debris & Alive \\
\hline Chelonia mydas & $2 / 17 / 2013$ & 33.8 & 34.4 & Likely hypothermia & Liquid content & Putrefied \\
\hline Chelonia mydas & $8 / 8 / 2014$ & 37.1 & 38.1 & $\begin{array}{l}\text { Unknown. Initially recovered } \\
\text { alive and released; after } \\
\text { one month only carapace } \\
\text { and } 2 \text { flippers found. }\end{array}$ & $\begin{array}{l}\text { Necropsy } \\
\text { impossible }\end{array}$ & Remains \\
\hline Chelonia mydas & $2 / 9 / 2014$ & 37.6 & 37.8 & Likely hypothermia & Partly full & Alive \\
\hline Chelonia mydas & $2 / 27 / 2015$ & 38.8 & 39.5 & Likely hypothermia & Partly full & Alive \\
\hline Lepidochelys kempii & ii 12/29/2011 & 24.4 & 24.7 & Likely hypothermia & Liquid content & Alive \\
\hline Lepidochelys kempii & ii 1/3/2012 & 23.7 & 24.0 & Likely hypothermia & Liquid content & Fresh dead \\
\hline Lepidochelys kempii & $1 / 4 / 2012$ & 25.7 & 26.1 & Likely hypothermia & Liquid content & Fresh dead \\
\hline Lepidochelys kempii & $1 / 7 / 2012$ & 26 & 26.4 & Likely hypothermia & Empty & Fresh dead \\
\hline Lepidochelys kempii & $2 / 6 / 2013$ & 26.6 & 26.9 & Likely hypothermia & Liquid content & Fresh dead \\
\hline Lepidochelys kempii & $2 / 21 / 2014$ & 23.9 & 24.1 & Likely oil pollution & Partly full & Alive \\
\hline Lepidochelys kempii & $3 / 4 / 2014$ & 22.3 & 22.5 & Likely hypothermia & $\begin{array}{l}\text { Feces collected } \\
\text { before death }\end{array}$ & Alive \\
\hline Lepidochelys kempii & $3 / 16 / 2014$ & 20.9 & 21.1 & Likely hypothermia & Empty & Putrefied \\
\hline Lepidochelys kempii & ii $\quad 4 / 5 / 2014$ & 23.9 & 24.2 & Likely hypothermia & Partly full & Alive \\
\hline Lepidochelys kempii & ii 12/30/2014 & 25.7 & 26.3 & Likely hypothermia & Partly full + marine debris & Alive \\
\hline Lepidochelys kempii & ii $1 / 17 / 2015$ & 24.3 & 24.7 & $\begin{array}{l}\text { Likely septicemia } \\
\text { and drowning }\end{array}$ & Liquid content & Alive \\
\hline Lepidochelys kempii & $2 / 23 / 2015$ & 24 & 24.2 & Likely hypothermia & Partly full & Alive \\
\hline
\end{tabular}

